\title{
A NEEDS ANALYSIS QUESTIONNAIRE FOR THE L2 CLASSROOM: INSIGHTS FROM A BRAZILIAN STUDY ON TASKS AND TECHNOLOGY
}

\author{
Um questionário de análise de necessidades para a sala de aula de L2: \\ insights de um estudo brasileiro sobre tarefas e tecnologia
}

Juliane Regina TREVISOL Universidade do Estado da Bahia

jtrevisol@uneb.br https://orcid.org/0000-0001-6847-2221

\begin{abstract}
Having in mind the importance of pilot studies for empirical investigations in applied linguistics, this article aims to describe a needs analysis instrument which was used as part of a study combining tasks \& technology (ELLIS, 2003; GONZÁLEZ-LLORET, 2016) for second/foreign language teaching in Brazil. In addition, the goal is to assist other practitioners who want to design classroom activities integrating digital technology into their practice. For that, the design and implementation of the needs analysis questionnaire is explained and data from seven learners of English as a foreign language (EFL) are analyzed. Overall, results suggest some relevant insights gained from such a proposal, regarding for instance the consideration of learners' linguistic and digital abilities, which may inform teachers when planning tasks for their language classes. Furthermore, for researchers, this movement reinforces the essentiality of conducting pilot studies as a way to reflect upon instruments, participants and specific contexts, therefore informing better routes for both research and pedagogical practices in different language learning and teaching environments. KEYWORDS: Digital technology; English language classroom; Instrument; Language teaching; Needs analysis; Task design.
\end{abstract}

RESUMO: Sabe-se que estudos pilotos são importantes para investigações empíricas em linguística aplicada. Desse modo, este artigo descreve um instrumento para análise de necessidades de aprendizes de línguas, utilizado como parte de um estudo que integrou tarefas e tecnologias (ELLIS, 2003; GONZÁLEZ-LLORET, 2016) para o ensino de segunda língua/língua estrangeira no Brasil. Ademais, objetiva-se assim auxiliar outros profissionais da área que queiram planejar e implementar atividades com tecnologia digital em suas práticas de sala de aula. Deste modo, o artigo apresenta inicialmente o planejamento e implementação do questionário utilizado e, na sequência, traz uma análise dos dados de 
sete aprendizes de inglês como língua estrangeira (ILE). De modo geral, os resultados sugerem alguns insights importantes obtidos através da proposta, tais como a consideração das habilidades linguísticas e digitais dos aprendizes, dentre outros aspectos, podendo servir de auxílio aos professores durante seus planejamentos de atividades em aulas de língua. Além disso, para pesquisadores, tal movimento reforça a importância de estudos-piloto que favoreçam a reflexão acerca dos instrumentos, participantes e contextos específicos, podendo portanto melhor informar caminhos tanto para pesquisa quanto para práticas pedagógigas em diferentes ambientes de ensino e aprendizagem de línguas. PALAVRAS-CHAVE: Análise de necessidades; Ensino de línguas; Instrumento; Plano de atividades; Sala de aula de inglês; Tecnologias digitais.

\section{INTRODUCTION}

There seems to be a scarce socialization of academic texts regarding pilot studies considering their importance for empirical investigations (VAN TEIJLINGEN; HUNDLEY, 2001). Pilot studies can be understood as "mini-versions of a full scale study", or as a "specific pre-testing of a particular research instrument such as a questionnaire or interview schedule" (VAN TEIJLINGEN; HUNDLEY, 2001, p. 1). Conducting a smallscale version of the full study seems to be relevant for various reasons. Just to cite a few, it is through pilot studies that a researcher can better design a research protocol, collect preliminary data, check a full-study viability, as well as test the adequacy of research instruments. Therefore, these mini-versions of a study seem to be paramount for providing insights about the processes and final outcomes, considering they can possibly "reveal subtle failures in the project structuring or in the study implementation which may not appear in the research plan"1, as explained by Bailer, Tomitch and D'Ely (2011, p. 130). Therefore, pilot studies may serve as a training function for the researcher aiming to increase the chances of success for the complete study to be subsequently carried out.

Taking those given elements into account, in order to be able to conduct a more carefully planned study on the interface of task-based language teaching (henceforth, TBLT) and digital technology, a piloting phase of one instrument was perceived as necessary. Thus, the present article aims to describe a needs analysis questionnaire -

\footnotetext{
${ }^{1}$ My translation. From the original: “(...) o estudo piloto é decisivo, uma vez que pode revelar falhas sutis na estruturação do projeto ou na implementação do estudo, que muitas vezes não estão aparentes no plano de pesquisa.” (BAILER; TOMITCH; D’ELY, 2011, p. 130).
} 
the instrument used for the pilot study — as a way to assist other teacher-researchers who want to design second language (L2) activities integrating digital technology into their classroom repertoire. For that, the design and implementation of the needs analysis questionnaire is explained and data from seven learners of English as a foreign language ${ }^{2}$ (EFL) are analyzed.

This way, the present paper is organized as follows: at first, the motivations and context of the study on tasks technology and L2 oral production are briefly presented; then, a discussion on the relevance of conducting needs analysis in the L2 classroom is introduced, followed by issues pertaining the method, regarding participants, the questionnaire and procedures for collecting data; and finally results are presented, followed by the final considerations, which explores some pertinent features noticed in the needs analysis and some examples of activities that could be considered for the classroom.

\section{Contextualizing a study on tasks, technology and L2 oral production}

As a teacher of EFL in the northeast of Brazil, I have always tried to diversify the types of practices and activities we have inside the classroom as a way to provide learners with different opportunities to use English, with a greater focus on meaning (e.g., sharing ideas, information, solving problems, communicating something they found interesting) and a smaller focus on linguistic elements (e.g., grammar in general). I also felt the need, as time passed, to let go of my teacher-centered practice so that, little by little, my learners could be the protagonists of our classroom interactions and activities. This mainly began when I started working with the task-based approach (ELLIS, 2003; NUNAN, 2004; WILLIS, 1996) while coordinating the PIBID Program (Programa Institucional de Iniciação à Docência) in my institution some years ago.

Years have passed while I kept on experimenting with different types of tasks, trying to find those that could trigger more successful L2 learning opportunities for my learners in that particular context. In recent years, considering the digital world most of us live in, the spread of new technologies and their access almost everywhere - for "people all over the world are walking around with powerful computers in their pockets and purses", as noticed by Prensky $(2005$, p. 1) in regards to our use of smartphones -

\footnotetext{
${ }^{2}$ Despite existing debates regarding the use of terms for learners of a language other than their first, and being aware that additional language might be a more appropriate term, in this paper the acronyms for foreign (FL) and second language (L2) will be used interchangeably for the sake of practicality.
} 
a question which has been constantly raised, among others, is this: How can technology assist L2 learning in the classroom? Of particular interest to me, taking into consideration my previous teaching and research experiences, was to better understand in which ways tasks and digital technology (the ones my students and I had access to, such as smartphones with WhatsApp) could be integrated in order to foster opportunities for them to learn and speak English ${ }^{3}$ — inside and outside the classroom. This is what motivated some further investigations on such issues, what leads us to the instrument to be presented in this paper: the needs analysis questionnaire, which was designed and piloted ${ }^{4}$ in order to unveil aspects considered to be essential when planning tasks with digital technology for the L2 classroom.

Now, what are tasks exactly? Despite the plethora of definitions in the literature, tasks - the main construct in the TBLT approach - may be understood as classroom activities intended to "develop language learning, in which learners use language, orally or in writing, with a focus on meaning"; through tasks, language is thus used "in order to create, communicate, or derive non-linguistic understanding — information, feelings, ideas or social relations" (BYGATE, 2015, p. xvi). In addition, Ellis' (2003, p. 9) criteria may also be useful for understanding that a task entails: 1) a workplan; 2) a primary focus on meaning; 3) real-world processes of language use; 4) use of any of the four language skills; 5) engagement of cognitive processes; and 6) a final product, that is, a clearlydefined communicative outcome.

This way, when teachers attempt to sequence some activities for the classroom, being that all of them form a cohesive whole which leads learners to produce something in the end (the final outcome), they may then have a task cycle. Now, when it comes to daily activities involving the target language, plenty are the possibilities of real-world tasks which may be used and can be transformed into complete cycles. When designing tasks, a final outcome may be, for instance, the organization of a trip - with flight and hotel reservations, considering one's (or a group's) given budget and schedule. It could also be the production of a short video reporting the adventures experienced on that trip

\footnotetext{
${ }^{3}$ In my teaching trajectory, L2 speech production has always been a compelling topic of investigation. Therefore, my research interests have revolved around the complexities of developing such a skill in the L2/EFL classroom considering learners' individual differences and needs.

${ }^{4}$ This pilot study was part of my doctoral dissertation, which investigated the enhancement of Brazilian learners' oral production in English through the use of digital storytelling tasks in the classroom.
} 
or presenting one's curriculum vitae when applying for a job online. A cycle could then include the preceding sub-tasks required for that given outcome to be reached, such as listing desired destinations, considering hotel facilities, flight prices and schedules, discussing on a best route to save time for the trip task ${ }^{5}$. As already pointed out, there are plenty of possibilities to be thought of when considering the creation and adaptation of tasks for the L2 classroom. Now, a question which is still worth investigating regards the ways these cycles can be conceived in order to involve different types of technology and digital resources - those that learners already use or have access to, for instance and which reinforce L2 speech production in particular learning contexts. Considering the lack of studies on that matter, especially in Brazilian EFL classrooms (TREVISOL, 2019), researchers and practitioners may have a lot to gain from such inquiries.

Speaking is in itself a complex skill to be developed (LEVELT, 1989). In addition to that, there seems to be a shortage of classroom opportunities for its practice and full development in L2 contexts, as pointed out by Appel and Borges (2011). Therefore, the investigation of whether using tasks with (some type of) digital technology may help enhance L2 oral production is justifiable. Also, in some contexts, it may have a significant impact on L2 development, not to mention on learners' motivation. It may be the case of Brazilian learners of English, for instance, considering that most of their formal learning in the language may happen inside school walls. However, how can we, teachers, know what types of tasks may be more effective for our groups? Or what types of digital tools can be used in the classroom in order to develop a given language skill? As pointed out by González-Lloret and Ortega (2014, p. 3), regarding what we now know about the integration of tasks and digital technologies for L2 learning, "a number of acknowledged fruitful synergies remains unfulfilled". One way to approach such questions and start formulating possible answers is by conducting a needs analysis (NA) with a particular group - this is, therefore, what this article aims to present in the following sections.

\section{The role of needs analysis for task design}

When aiming to integrate tasks and technology in the classroom, three main steps may be suggested: 1) first, design a questionnaire as an NA instrument, considering the context where the study will take place or the particular group of students who will be

\footnotetext{
${ }^{5}$ For those interested, Pereira (2015) and Afonso (2016) are some examples of Brazilian studies involving task cycles.
} 
doing the tasks; 2) then, implement it, have learners answer it; and 3) finally, analyze the data gathered in order to reflect about it, and think of possible tasks which would best serve those learners you have ${ }^{6}$. For the present investigation, the specific context was that of an undergraduate teacher-training program in the northeast of Brazil; therefore, learners here were future English teachers who lived in rural areas, far from metropolitan cities. The purpose of the questionnaire was then to learn about these students' preferences and their digital skills. Knowing that in advance would render the design of more adequate tasks for that specific audience.

Because the task-based approach, as a principle, has its focus on the learner and his/her L2 needs, desires, motivations, and main learning objectives -, NA is usually recommended as a first pedagogical phase in a TBLT curriculum or syllabus organization by many of its advocates (e.g., GONZÁLEZ-LLORET, 2014, 2016; GONZÁLEZLLORET; ORTEGA, 2014; LONG, 2005, 2015). For its diagnostic function, despite being quite time consuming, conducting a NA is understood as essential "in just the same way we would expect physicians to diagnose what ails us before prescribing a treatment" (LONG, 2015, p.11), especially when we think of the diversified populations of language learners we have, considering the particularities of our (local) contexts.

In regards to technology-mediated TBLT, González-Lloret (2016, p. 17-18) - a leading scholar in this interface - explains that, in addition to information on the tasks themselves (what the learners will be required to do in the L2) and the language required for task completion, information regarding technology is also extremely relevant. This way, a NA should inform what tools to use for accomplishing the task, which digital skills learners have, how accessible technology is, among others related aspects.

For those interested in using tasks as a $\operatorname{support}^{7}$ (LONG, 2015) for classroom activities, such as myself, — and specially including technology in it - , the first suggestion González-Lloret (2016) gives is to gather as much information as possible in your NA: this way you may create a more adequate picture of the learners, the context, and the tasks you may design and sequence. Questionnaires are one of the most frequently instruments used, and they seem to be the least complicated form to collect such data ${ }^{8}$.

\footnotetext{
${ }^{6}$ These were the steps followed in the pilot study. It was only after that that the task cycle was conceived.

${ }^{7}$ That is, not necessarily following an entire TBLT curriculum, for instance.

${ }^{8}$ Other suggested ways to collect data are through interviews, audio or video recordings, context observations, and focus groups (GONZÁLEZ-LLORET, 2016).
} 
However, as the scholar explains, "creating a good questionnaire takes time and expertise" (p. 26) and testing this instrument when it is considered complete is strongly advised. Practitioners may also consider: a) What tasks will students need to perform after they finish our program and either graduate from the university or continue their language education? b) Are any of these tasks mediated by technology?(GONZÁLEZ-LLORET, 2016, p. 27). Now, regarding language specifically and other elements to be considered, some questions that might be asked are: c) What language is needed to accomplish these tasks? d) What language do students already speak? e) What digital skills do students (and teachers) already possess? f) Could our institutional context support the teaching of such tasks? (GONZÁLEZ-LLORET, 2016, p. 27). Considering such aspects may guide this diagnostic phase in a more appropriate manner.

In my study in particular, attention was given mainly to issues related to technology: how acquainted learners were with certain digital tools and resources, how accessible technology (e.g., the internet, or a smartphone or a computer) was for them. Taking all that has been presented into consideration, an NA questionnaire may be understood as a complete and informative tool for collecting data on L2 learners' background information (e.g., informing on socio-economic status), general L2 use, and technology skills, in addition to preferences in regards to topics of interest, learning styles and beliefs, for instance ${ }^{9}$. Additional aspects related to this given tool are to be reported next.

\section{METHOD}

\section{Participants}

The pilot study gathered data from a total of seven EFL learners (4 women and 3 men), with Brazilian Portuguese as their mother-tongue, enrolled in the English Language Program at a public university in the northeast of Brazi ${ }^{10}$. The program, composed of eight semesters total, provides learners with an English teaching degree. Participants' ages ranged from 18 to $29(\mathrm{M}=22)$. In addition, they all resided in non-cosmopolitan areas of the state, 3 in the town where the university is located and the others in nearby communities (having to travel daily, with public transportation, to attend classes). At the

\footnotetext{
${ }^{9}$ The questionnaire is available in the end of the article (Appendix A).

${ }^{10}$ Information presented here came from Part 1 of the NA questionnaire. It is, thus, part of the results of the pilot study.
} 
time of data collection, 4 participants were attending the English Intermediate I classes (P2 ${ }^{11}$, P5 , P6, P7) and 3 of them the Advanced II classes (P1, P3, P4). Only two had taken classes in private language courses before entering university (P4 and P6), though all of them had English classes during Elementary school. This specific public was selected with the aim of contributing to that given context, by critically reflecting upon relevant issues related to classroom-based research, for instance - especially because this is an underresearched population ${ }^{12}$ (considering task-based studies conducted in Brazil) in an EFL environment. Furthermore, the intention was also to raise discussions on teacher education, considering the participants were future English teachers in the Brazilian context.

\section{The needs analysis questionnaire: Parts 1, 2 and 3}

The instrument was designed using Google forms, a free online tool of simple access which allows you to create questionnaires, send them to participants, as well as receive answers in a friendly mode which facilitates the analysis afterwards. It may also be used by teachers, for instance, to prepare quizzes or tests that learners can take online. For the study, the NA questionnaire ${ }^{13}$ was designed and applied in Portuguese in order to avoid L2 interferences, considering that learners' proficiency levels in English might have been different. It included a consent form right at the beginning to attest learners' free participation in the study. The choice of applying an online questionnaire was due to time and geographical constraints ${ }^{14}$ — the teacher-researcher being in the south and participants in the northeast of the country (an approximate distance of three thousand kilometers). This way, technology was of great assistance for research purposes here since, otherwise, data could not be gathered so promptly.

Regarding its organization, the questionnaire was composed of three main

${ }^{11} \mathrm{P}$ stands for Participant. They were numbered according to the order they answered the questionnaire.

${ }^{12}$ According to the national Census of IBGE (2010), both the north and the northeast regions of Brazil are characterized as having lower schooling levels when comparing to other regions, for instance.

${ }^{13}$ The full questionnaire can be found in Appendix A. It is the same questionnaire used in Trevisol (2019).

${ }^{14}$ And also because the initial idea of applying it in person had to be changed due to a strike at university. 
parts: a) Part 1, which referred to personal questions; b) Part 2, which inquired about the relationship between the learner and the English language; c) and Part 3, which gathered information about issues concerning the learner and digital technology (access, use). Responses to questions were overall mandatory, that is, learners were expected to provide an answer, with the exception of those items in which a negative response was given ${ }^{15}$. A total of 71 questions appeared in the five pages of the online Google form. Most were closed questions (48 out of 71), either of multiple choice in which only one option should be selected, or with more than one alternative being possible for selection. Some questions were also in the form of a Likert scale, inviting learners to grade certain activities ${ }^{16}$. Furthermore, the remaining 23 open-ended questions ${ }^{17}$ required participants to justify their answers so that more information on a certain topic would be given.

More specifically, with Part 1, a background profile of the participants could be built: questions informed about age, marital status, place of residence, year of entrance at university, semester attending at that moment, reasons for choosing the English teaching program, among others ${ }^{18}$. With Part 2, entitled You and the English language, a more qualitative profile of learners could be built regarding, for instance: a) whether or not they studied English formal or informally before and after entering university; b) how often certain activities were done weekly (e.g., watching movies, reading books or articles in English); c) how important English was for their daily routines. Also, it was important to understand the relevance of certain classroom activities for their own learning, the discussion topics they favored in class, as well as how they could self-assess their own learning styles and preferences, among other aspects.

Since participants were future EFL teachers, questions on Part 2 also inquired about whether they had already taught the language and how they felt about the experience.

\footnotetext{
${ }^{15}$ For instance: in a question such as 'Q1. Do you have kids?', when a learner marked 'No', the following question 'Q2. If yes, how many?' would not demand an answer.

${ }^{16}$ For instance: in Question 5 from Part 2, learners decided on how much 'a classroom activity using videos' would contribute to their learning progress, on a scale of 1 to 5 (being 5 highly important and 1 not important at all).

${ }^{17}$ In specific terms, thus, the division was as follows: a) Part 1 consisted of 14 questions total, of which 5 were open and 9 were closed; Part 2 consisted of 32 questions total, of which 11 were open and 21 were closed ( 2 of these carrying the exception that participants had to justify their answers, so a secondary part of it was also open-ended in a way (e.g., questions 4.1 and 5)); and finally Part 3 consisted of 25 questions total, of which 7 were open and 18 were closed.
}

${ }^{18}$ For more information, see the questionnaire available in Appendix A. 
At last, they were invited to comment about what they understood learning and teaching were, as well as their beliefs about what being a (good) teacher and a (good) student entails. This second part, as it may be noticed, required learners to reflect and discuss in a deeper manner about certain issues; this was seen as relevant so that a more holistic picture of the participants - where they were coming from - could be made.

Finally, in Part 3 - You and digital technology —, questions aimed at understanding the connection these learners had with digital technology, considering mainly: a) how often they accessed the internet; b) what sorts of media they frequently used (e.g., radio, news, social media such as Facebook, Instagram, websites, blogs); c) which media was used for English practice and with which focus (e.g., for grammar or listening practice). Questions also unveiled whether they used Skype, played online games, were familiar with video making tools, sent audio messages in English using Whatsapp and whether they felt comfortable when speaking the L2, among other issues. As already mentioned, gathering data on their familiarity with technology was fundamental for planning the subsequent stages of the study (e.g., considering what types of activities would be included in the task cycle, especially taking into account that L2 oral production using some sort of digital tool was part of the plan).

\section{Procedures for collecting data using the questionnaire}

Participants for the pilot study were informally recruited in November, 2017. An invitation to respond to the questionnaire was emailed to undergraduate students from different semesters of the English program, after being informed they would be freely ${ }^{19}$ collaborating with the study in case they accepted. Only 7 participants replied ${ }^{20}$. In the email, participants were guided to complete the form by clicking on the box preencher formulário (fill in form). After clicking on it, the survey link would open with the consent form on its first page. If accepting to participate, the learner would then click on próximo (next) to get to page 2, in which another welcoming part awaited.

In page 2, the study's main goal appeared again in order to reinforce the importance of getting to know learners and their preferences in terms of EFL learning and teaching.

\footnotetext{
${ }^{19}$ In Brazil, different from some other countries, it is prohibited to pay participants to take part in a research study.

${ }^{20}$ The small number of replies might have been because data collection happened at the end of the year (close to holiday season); also, learners might have been overloaded with final assignments due to the strike previously mentioned.
} 
Information regarding the general time spent for responding the questionnaire was also given here (which was approximately 30 minutes). This part was followed by the question flow chart, which showed them the three main parts of the questionnaire. For every page the participant was accessing, there was a blue bar on the bottom right indicating how much remained to be completed, an interesting element of this tool, since it allowed the learner to keep track of what still needed to be accomplished.

\section{RESULTS AND DISCUSSION}

Because the NA questionnaire was quite lengthy, results presented here will refer only to some relevant aspects noticed ${ }^{21}$. Considering Part 1 of the questionnaire was already summarized on the Participants section, results pertaining Parts 2 and 3 will be described in the following paragraphs. Aspects here analyzed mainly inform about participants' general contact with the English language, inside and outside the classroom, as well as their present use of digital technology — elements which need to be acknowledged for task design (and implementation), which may render more successful L2 learning opportunities in the classroom, especially when attempting to connect technology with tasks that engage learners in producing language meaningfully.

\section{Learners and the English language}

Considering language contact, the initial questions in Part 2 informed about whether L2 learners had had previous contact with English before starting the undergraduate teaching program. Answers showed that all of them had already studied English, mainly at Elementary school (71\%), while only 2 mentioned having studied it at private language schools (28\%). Also, all reported being open to search for additional learning opportunities on their own outside of the classroom, what may imply they understand the relevance of maintaining a certain frequency of contact and practice so that the L2 can be more successfully learned. In what regards their learning routine at home, they all

\footnotetext{
${ }^{21}$ Relevant aspects here are those related to learners' contact with English outside the classroom, their main preferences, topics of interest and types of in-class activities favored, their major challenges in terms of language, their digital skills and issues of access to different digital technology resources. All of them may inform the teacher-researcher when designing and implementing tasks with technology in the L2 classroom. However, the full questionnaire gathered additional which will not be discussed in detail in the article (e.g., socioeconomic status, parents' schooling information, participants' teaching experience).
} 
reported listening to music regularly. Moreover, 5 of them $(71 \%)$ have indicated using their study materials (e.g., coursebook, CDs) to study, as well as watching series and/ or movies (at least with the audio in English). In addition, 4 learners (57\%) mentioned reading books and also accessing blogs and websites for $\mathrm{L} 2$ practice.

Furthermore, they all acknowledge the importance of English in their life for professional reasons $(100 \%)$ - which is not a surprise considering they are attending an eight-semester teaching course, as P1 illustrates: "I am an English teacher, so I need to have an overall domain over the language, in addition to it being a basic necessity considering the growing advance of English worldwide"22. Moreover, they all perceive English as a necessity nowadays (100\%), as P5 exemplifies: "The English language is fundamental for everything. Having English as a second language opens many doors, especially in the job market". Affective reasons were also mentioned (71\%) — "I personally like the language, so I want to learn it" (P6) - "especially when recognizing it may be a way to expand ones' knowledge horizons in a language other than your mother tongue", as P6 concludes. Nonetheless, only 3 participants have indicated their personal desire to become English teachers (43\%) and 3 others wanted to become translators.

Regarding in-class activities, the most favored were those that make use of diversified written texts, while listening comprehension and speaking activities seemed to be the types of activities they did not enjoy much. Furthermore, activities involving the use of videos and music also received positive ratings by all participants, as well as activities in which learners had to assume the role of the teacher to teach their colleagues. Now, considering the possibility of doing activities in a virtual environment, responses were rather mixed - many being negatively rated. For instance, virtual activities using written texts were reported as not contributing much to learning (42.9\%). This might be explained by their lack of familiarity ${ }^{23}$ with platforms such as Moodle, among others, which are not commonly used in the given context (and even made available by the institution, at the time of data collection at least). A comment from P3 reinforces that: "I believe many times these activities in virtual environments are not so valid, considering the lack of practice many of us face when accessing these virtual spaces". In addition,

\footnotetext{
${ }^{22}$ Since participants' responses were in Portuguese, direct citations are my translation.

${ }^{23}$ This is implied in participants' answers in general, even though the English program has a discipline which deals with new technologies and distance learning. A limitation perceived in the questionnaire was the lack of questions informing, for instance, whether learners had already taken any virtual courses or had experienced distance education somehow. Further investigations should take that into consideration.
} 
P4 raises another concern, by pointing out that "activities in the virtual environment have the shortcoming of lacking assistance when any type of doubt emerges", that is, feedback and support from the teacher or tutors may not be immediate or perhaps even inexistent. This negative aspect has already been reported by researchers (e.g., PETERSON, 2010) conducting experiments in distance learning contexts or considering computer-mediated interactions. Therefore, this raises questions to be addressed in distance education programs, especially.

Participants also had to select from a 23-item list which topics they found more interesting for in-class work and discussion. Overall, results were: a) 6 learners (85\%) chose social media, such as Facebook, Instagram, WhatsApp, as well as issues that involve cultural aspects as favorite topics; b) 5 learners (71\%) chose topics related to series/films, reading habits, and world news; c) and 4 learners (57\%) selected issues of gender, race, identity, or related to their own local communities, and to language teaching and learning in different contexts.

\section{Language learners and digital technology}

Regarding technology, it was observed that all participants had access to the internet through their notebooks, personal computers and/or smartphones, and they used it on a daily basis, by the time of data collection. Internet access was available mainly at home, though two participants mentioned accessing it at a friend's home and one at university.

Learners also reported checking social media (e.g., Facebook) as well as using different websites daily; four mentioned reading blogs and Vlogs as well. They also mentioned using these resources, among others (e.g., TV), for studying English. Some websites were reported for L2 practice (especially for improving grammar and vocabulary), such as: My English online, TOEFL grammar, Duolinguo (cited by P1), English in Brazil at YouTube, English Experts, Duolingo (by P4), Bravolol, ABA English (P6), Google translator, Oxford dictionary, YouTube (by P7). YouTube served mainly for pronunciation practice and for learning about the English culture for P7. All in all, these learners seem to be autonomous and proactive, to a certain extent, searching for additional opportunities to expand their linguistic and intercultural knowledge, being somewhat concerned with learning the language they are about teach ${ }^{24}$.

\footnotetext{
${ }^{24}$ Only 2 of them reported being working as teachers at the time of data collection.
} 
Regarding learners' familiarity with certain technological tools, most participants mentioned never using Skype (71\%), and 2 reported having already used it to practice English. Most of them never played online games in which L2 interaction with other players was a requirement (86\%). Only P4 reported frequently playing the following online games - Overwatch, Counter Strike GO, and Beawlhala. Four participants replied positively to having already produced a video in English (57\%) using their smartphones. However, only one learner was acquainted with movie-making and editing softwares such as Moviemaker ${ }^{25}$. Therefore, it seems only a few of these learners were in general acquainted with online gaming, video-conferencing and video-making software, even though smartphones have been used for producing videos in which spoken English was required, for instance, as reported.

Now, considering participants' L2 oral abilities, all of them replied having already sent an audio message in English via WhatsApp and reported it as a positive experience. They all reported feeling comfortable speaking English — I feel like English is my mother tongue, as illustrated by $\mathrm{P} 7$ - , mainly when interacting with colleagues (P5) or in a friendly environment (P6). However, despite being somewhat confident, speaking is acknowledged by learners as a challenging skill — it was rated by most with a moderate level of difficulty (71\%) when compared to reading, writing or listening. In that sense, P4 points out the need of practice to improve L2 oral performance - stating that Practice makes it better ( $\mathrm{P} 4)$ - , an aspect which is in line with the Output hypothesis, proposed by Swain (1993; 1995) and Swain and Lapkin (1995), whose claim reinforces the demand to produce language in order to learn language. According to the scholars, during speaking (or writing, for that matter), learners have the opportunity to test their own hypotheses about the language, to notice L2 gaps in their performance - gaps related to what they can say and what they want to say - and to raise awareness on some linguistic elements. All of that is essential for successful L2 learning.

Last but not least, of the four language skills, listening was the one considered the most difficult by 4 learners $(57,2 \%)$. Reasons varied from lack of practice to insufficient lexical knowledge. Just for illustration, P1 explains feeling quite nervous while trying to

\footnotetext{
${ }^{25}$ For teachers who want to experiment with Skype or have students create digital stories (which require their ability to manage movie-making programs), such pieces of information seem to be quite informative. Considering such data, for instance, a teacher could first attempt to think of a task in which learners use WhatsApp to produce some short oral interactions, instead of an activity using Skype, for instance. Now, if the teacher expects learners to create videos and use specific software for that, it is advisable to provide learners with workshops and tutorials so that they can master the program first to be able to accomplish the digital storytelling task later.
} 
understand an oral message, in addition to the lack of familiarity with different accents that also hinders comprehension, as he adds. The participant also clarifies that too fast speech and poor vocabulary also make listening extremely difficult (P1).

Overall then, one might notice that participants are aware of linguistic aspects that require more attention from their part, perceiving that additional practice may possibly solve some of those difficulties reported, as well as expand L2 vocabulary on a range of different topics. With information provided from analytical instruments, therefore, teachers and researchers may gain valuable insights into what sorts of materials, topics, tasks, digital tools (so on and so forth) may be more adequate for that particular group of learners and contexts. Furthermore, considering these elements may result in more rewarding 'experimentations' with technology in the real classroom, for both teachers and learners.

\section{FINAL CONSIDERATIONS}

One of the main goals of this article was to describe a needs analysis questionnaire which was used in a pilot study in technology-mediated TBLT, understanding it — or part of it - could be of assistance for other teachers when planning activities that integrate digital resources in the $\mathrm{L} 2$ classroom. In addition to describing the questionnaire and how it was implemented, data from a specific population — its respondents - was analyzed: EFL undergraduate learners from the northeast of Brazil, future English teachers, whose data provided valuable insights that will serve for the following phase: the design and implementation of appropriate tasks for that given population.

Apart from several aspects that have been previously discussed, results of the NA questionnaire have provided information about how autonomous learners were in general, considering for instance the ways they kept in contact with English outside of class (giving hints of their proficiency level), their acquaintance with technological tools and whether or not they have internet access available to them at home, among other issues. With that, teachers may reflect about the types of activities that may best serve these learners and which projects and topics they might prefer, assuming it would render more engagement and participation both inside and outside the L2 classroom if these were considered during task design.

Even though participants here informed 'feeling comfortable' when speaking English, L2 oral production may be quite a challenge for other groups of learners, especially at pre-intermediate or beginner levels - and this will also reflect on the types 
of tasks to be designed and included in the task cycle. Beginners, for instance, may require more assistance on the part of the teacher, or more time on task, so some (sub) tasks might be considered, as home assignments or in-class activities, to avoid additional difficulties; also, having learners work in pairs or groups might be another possibility ${ }^{26}$ to overcome challenges regarding L2 production in lower levels. This way, assessing proficiency before task design may be quite important due to the variability that might exist (in L2 competence) when taking an entire group (e.g., an intact classroom) into perspective. In other words, it might be that not all learners enrolled at an Advanced II course might be considered 'advanced' if a standardized proficiency test were to be applied, for instance. Therefore, depending on task requirements (in terms of language skills), having this aspect considered beforehand might make a difference in performance.

Furthermore, considering their digital skills is also fundamental, mainly when the task entails technology use and manipulation. Take a video-making activity, for instance, in which different tasks are proposed so that a final video, with its edited pieces, is to be put together. Would these learners be able to do it by themselves? Probably not without a certain degree of difficulty (or probably yes though not without further help), considering most of them are not familiarized with movie-editing software, despite being able to use their cellphone cameras to record a video. Henceforth, in a task involving video-making, a video-editing workshop (using a free software, such as Moviemaker for instance) - in which learners have a hand-on experience with editing images, sound, their oral narrations, pieces of videos, transition effects and so on - might be essential. Such a video, also known as a digital story $^{27}$ (LAMBERT, 2007; NISHIOKA, 2016), could display some cultural aspects of their hometowns, communities or 'povoados', reflecting elements they want to illustrate, reinforce or critically discuss; it could also be an informative appraisal of learning styles to reflect on how learners, as individuals, differ in so many ways (e.g., Dörnyei, 2005). Ideas such as these are in line with these participants' preferences and topics of interest which were noticed in the data analysis.

\footnotetext{
${ }^{26}$ The list of suggestions or considerations may be expanded depending on the target audience, the local L2 learning and teaching context, its facilities, and so on. That is why conducting a needs analysis makes a difference before designing and implementing any sort of task or classroom activity to a given group of learners - even more important in the case of empirical studies, considering its need for careful methodological planning so that its validity can be attested, for instance.

${ }^{27}$ For a study involving digital storytelling in an EFL classroom in Brazil, see Trevisol and D'Ely (2019).
} 
All in all, as it has been pointed out, conducting the pilot study was relevant - even if only for exploring the needs of one EFL group, as done here - considering it was an essential step for critically reflecting about possible projects, L2 knowledge skills, and types of digital technology resources to be used when planning a task cycle for enhancing L2 oral production (as well as any other skill) in the classroom. This way, the NA questionnaire was perceived as a legitimate tool to capture wealthy knowledge on participants' overall characteristics and ways in which they may deal with the L2 learning process. Instruments such as this may guide other practitioners and researchers who wish to diagnose some aspects in different EFL environments, at an initial stage, with the aim of informing further pedagogical actions that are to come.

Furthermore, insights from a NA may assist the selection of digital technology tools for use in the L2 classroom (such as Skype, Moviemaker, WhatsApp, online dictionaries), provided the context has internet access, among other issues that might be considered. Also, data regarding the moderate difficulty that $\mathrm{L} 2$ oral production raises in participants here instigates the reflection of how this skill — as well as the other skills, integrated may be more adequately fostered in the classroom, and in studies in particular. Because speaking is a complex skill (LEVELT, 1989), more time and opportunities for practice should be devoted to it, especially when learners may not be so confident in using the target language orally.

Finally, as I see it, experimenting in the classroom - with new tools, methods, digital resources, different task types and topics, and so on - is usually part of our teaching routines. It is also quite challenging at times, perhaps even more now that digital technology seems to be changing so fast. It may be especially challenging for those who tend to feel the need to control their surroundings almost entirely (I am still one of those teachers, even though I fight to change it on a daily basis - and that is why the task-based approach has been a good companion in my pedagogical practice for some years now). Taking that into consideration - and keeping in mind Bygate's (2015) words that "as an area of Applied Linguistics, TBLT is an empirical project" (p. xxiii) - it is my hope that more teacher-researchers may engage in experimenting with different tasks and different types of technology in their classes, if (and only if) they understand it to be beneficial (for L2 learning, for their own learning). Further studies are also needed so that more is known, both in terms of research and L2 pedagogy, about ways to integrate technology in other L2 environments. This may hopefully motivate 'innovative' practices in a variety of EFL/L2 contexts, inspiring other practitioners to experiment, in an informed way, technology-mediated tasks in their local realities. 


\section{REFERENCES:}

AFONSO, J. C. What role do tasks play in an EFL environment? Unfolding 9th grade learners' perceptions on the implementation of a cycle of tasks on the first chapter of 'Harry Potter and the Sorcerer's Stone'. Unpublished master thesis. Universidade Federal de Santa Catarina, Florianópolis, 2016.

APPEL, C.; BORGES, F. Task design for L2 oral practice in audioblogs. The EUROCALL Review, v. 20, n. 1.Proceedings of the Eurocall Conference, 2011.

BAILER, C.; TOMITCH, L.; D’ELY, R. Planejamento como processo dinâmico: a importância do estudo piloto para uma pesquisa experimental em linguística aplicada. Revista Intercâmbio, v. XXIV, 129-146. São Paulo: LAEL/PUCSP, 2011.

BYGATE, M. Introduction. In M. Bygate (Ed.), Domains and directions in the development of TBLT. Amsterdam: John Benjamins, 2015.

DÖRNYEI, Z. The psychology of the language learner: individual differences in second language acquisition. Mahwah, NJ: Erlbaum, 2005.

ELLIS, R. Task-based language learning and teaching. Oxford: Oxford University Press, 2003.

GONZÁLEZ-LLORET, M. The need for needs analysis in technology-mediated TBLT. In M. González-Lloret\& L. Ortega (Eds.), Technology-mediated TBLT: researching technology and tasks (pp. 23-50). Amsterdam: John Benjamins, 2014.

GONZÁLEZ-LLORET, M.A pratical guide to integrating technology into task-based language teaching. Georgetown University Press, 2016.

GONZÁLEZ-LLORET, M; ORTEGA, L. Technology-mediated TBLT: researching technology and tasks. Amsterdam: John Benjamins, 2014.

IBGE. Instituto Brasileiro de Geografia e Estatística. Censo demográfico 2010. Rio de Janeiro, 2010.

LAMBERT, J.Digital storytelling cookbook. Berkely, CA: Digital Dinner Press, 2007.

LEVELT, W. J. M. Speaking: from intention to articulation. Cambridge, Massachusets: The MIT Press, 1989. 
LONG, M. H. Methodological issues in learner needs analysis. In M. H. Long (Ed.), Second language needs analysis. Cambridge, UK: CUP, p. 19-76, 2005.

LONG, M. H. Building the road as we travel. In M. Bygate (Ed.), Domains and directions in the development of TBLT. Amsterdam: John Benjamins, p. 1-26, 2015.

NISHIOKA, H. Analysing language development in a collaborative digital storytelling project: Sociocultural perspectives. System, v. 62, p. 39-52, 2016.

NUNAN, D. Task-based language teaching. New York, NY: Cambridge University Press, 2004.

PEREIRA, G. D. The development and implementation of tasks to elderly learners of English as a foreign language: Taking a bigger picture into consideration. Unpublished master thesis. Universidade Federal de Santa Catarina, Florianópolis, 2015.

PETERSON, M. Task-based language teaching in network-based CALL: An analysis of research on learner interaction in synchronous CMC. In M. Thomas; H. Reinders (Eds.), Task-based language learning and teaching with technology (p. 41-62), London: Continuum, 2010.

PRENSKY, M. What Can You Learn From A Mobile Phone? - Almost Anything. Innovate: Journal of Online Education, 1 (5), p. 1-8, 2015.

SWAIN, M. The output hypothesis: just speaking and writing isn't enough. The Canadian Modern Language Review, v. 50, p. 158-164, 1993.

SWAIN, M. Three functions of output in second language learning. In: G. Cook\& B. Seidhofer (Eds.) Principles and practice in applied linguistics. Oxford University Press, 1995.

SWAIN, M.; LAPKIN, S. Problems in output and the cognitive processes they generate: A step towards second language learning. Applied Linguistics, v. 16, p. 371-391, 1995.

VAN TEIJLINGEN, E. R.; HUNDLEY, V. The importance of pilot studies. Social Research Update, v. 35, p. 1-4, 2001.

WILLIS, J. A framework for task-based learning. Harlow: Longman, 1996.

TREVISOL, J. R. Investigating L2 learners' oral production and perception of a task cycle using digital storytelling: a case for technology-mediated TBLT. Unpublished doctoral dissertation. Florianópolis, Universidade de Santa Catarina, 2019. 
TREVISOL, J. R.; D'ELY, R. C. F. Tarefas e histórias digitais na sala de aula de línguas: efeitos na produção oral em L2. In Oliveira, D.; Silva, I. T. (Eds.), Fundamentos e práticas no ensino da língua inglesa: Volume I - Resultados e propostas de pesquisa (pp. 79-92). Alagoinhas: Bordô-Grená, 2019.

Recebido em: 04 out. 2019 Aceito em: 08 mar. 2020 